\title{
Morphology, myxocarpy, mineral content and in vitro antimicrobial and antiproliferative activities of mericarps of the vulnerable Turkish endemic Salvia pilifera
}

\author{
Sevda GÜZEL 1 * (D), Ahmet KAHRAMAN 2 (D), Mahmut ÜLGER 3 (D), Yusuf ÖZAY 4 (D), \\ İbrahim BOZGEYİK 4 (D), Özkan SARIKAYA 5 (i)
}

1 Department of Pharmacognosy, Faculty of Pharmacy, Mersin University, 33169, Mersin, Turkey.

2 Department of Biology, Faculty of Arts and Science, Uşak University, 64200, Uşak, Turkey.

3 Department of Pharmaceutical Microbiology, Faculty of Pharmacy, Mersin University, 33169, Mersin, Turkey.

4 Department of Medical Biology, Faculty of Medicine, Adıyaman University, 02040, Adıyaman, Turkey.

5 Department of Child Development, School of Health, Kırsehir Ahi Evran University, 40100, Kırşehir, Turkey.

* Corresponding Author. E-mail: guzelsevda@mersin.edu.tr (S.G.); Tel. +90-553-126 3692.

Received: 26 February 2019 / Revised: 05 May 2019 / Accepted: 21 May 2019

ABSTRACT: Salvia L., the largest genus of the family Lamiaceae, is composed of many well-known plants of medicinal value. This study provides the first data on micromorphology, myxocarpy, mineral content and in vitro antimicrobial and antiproliferative activities of mericarps of Salvia pilifera, considered to be a vulnerable endemic species from Turkey. The macro- and micromorphological mericarp traits were documented and illustrated via stereo microscopy and scanning electron microscopy. Mineral content of mericarps was analyzed using ICP-MS. Ethanol extract of mericarps was tested against Staphylococcus aureus, Bacillus subtilis, Escherichia coli, Acinetobacter baumannii, Aeromonas hydrophila, Candida albicans, Candida tropicalis, and Candida glabrata using broth microdilution method. Antimycobacterial activity was performed against Mycobacterium tuberculosis H37Rv using resazurin microtiter plate method. Ampicillin, Ethambutol, Isoniazid, and Fluconazole were chosen as reference drugs. Antiproliferative effect of the extract was tested against A549 human lung cancer cell lines using MTT test. The size of the mericarps was $4.38 \pm 0.17 \mathrm{~mm}$ in length and $3.28 \pm 0.13 \mathrm{~mm}$ in width. The general shape was elliptic to widely elliptic. The abscission scar was nearly rounded. The ornamentation pattern of the surface was colliculate with polygonal exocarp cells. Myxocarpy was observed on the surface of the mericarps when they become hydrated. Transparent mucilaginous cells showed a moderate reaction with extensions more than $0.1 \mathrm{~mm}$ long. Potassium and calcium were determined as major minerals $(80.662 \pm 0.234$ and $41.892 \pm 0.399 \mu \mathrm{g} / \mathrm{g}$, respectively). The extract showed greater antibacterial activity against A. baumannii compared to Ampicillin (62.5 and $125 \mu \mathrm{g} / \mathrm{mL}$ MIC values, respectively). Cell viability level of the extract $(100 \mu \mathrm{g} / \mathrm{mL})$ was found to be statistically lower than control group against A549 human lung cancer cell lines $(\mathrm{P}<0.05)$.

KEYWORDS: Salvia pilifera; SEM; fruit; mucilage; morphology; mineral content; antimicrobial activity; cell viability.

\section{INTRODUCTION}

Salvia L. (sage) is the most species-rich genus of Lamiaceae (mint family) with ca. 1000 species and a worldwide distribution. One of the main centers of diversity of Salvia is South-west Asia where Turkey is apparently the largest number of species with 100, including 53 endemics [1].

Different traditional uses of Salvia species such as treatment of cancer, microbial infections, inflammation, bronchitis, tuberculosis [2], menstrual disorders, the common cold [3] have been reported. Moreover, the genus has been used as folk remedy in tea form against simple disorders in Anatolia [4] and for memory enhancement in European folk medicine [5]. The presence of flavonoids, phenolic acids [6], terpenoids [7], fatty acids [8, 9], tocopherols [10], amino acids [8, 11], and minerals [9, 11, 12] have been reported in different parts of Salvia species. In previous studies, antibacterial, antifungal, wound healing [13], antiproliferative [14, 15], antitubercular, cytotoxic [3], antioxidant [16], acetylcholinesterase and butylcholinesterase [7] activities of Salvia species have been determined.

Salvia pilifera Montbret et Aucher ex Benth. in the section Salvia is a perennial endemic species mainly distributed in the eastern Mediterranean region of Turkey, occasionally in Southeast Anatolia. This species is an Irano-Turanian element and is found on limestone slopes, in Quercus scrubs and among bushes and

How to cite this article: Güzel S, Kahraman A, Ülger M, Özay Y, Bozgeyik I, Sarıkaya Ö. Morphology, myxocarpy, mineral content and in vitro antimicrobial and antiproliferative activities of mericarps of the vulnerable Turkish endemic Salvia pilifera. J Res Pharm. 2019; 23(4): 729-739. 
macchie. The species is assessed as Vulnerable (VU) at national and global levels using IUCN Red List categories and criteria [17]. The fruit of Salvia is a dry, four-lobed, schizocarp that fragments into four, singleseeded, non-dehiscent mericarps or nutlets. The mericarps function as seeds, and hence sometimes they are commercially called seeds in the food industry [18].

So far, mericarp morpholoy and myxocarpy of different Salvia species have been investigated $[1,19$ 24]. However, the mericarp structure and the presence/absence of myxocarpy of most Salvia species in the world have not yet been studied. Except essential oil composition, antioxidant and antimicrobial [25] activities, and cytotoxic effect on DU145 prostate cancer cell lines [15] of aerial parts, no data on micromorphological characters, myxocarpy, mineral content and in vitro antimicrobial and antiproliferative activities of mericarps of the vulnerable Turkish endemic S. pilifera have been reported in the available literature. Hence, this study aims to present the following information on S. pilifera: (i) quantitative and qualitative morphological mericarp properties; (ii) illustrations with stereo microscopy (SM) and scanning electron micrographs (SEM); (iii) the presence/absence of myxocarpy and mucilage characteristics; and (iv) mineral content and in vitro antimicrobial and antiproliferative activities of the mericarps.

\section{RESULTS}

In the present study, yield percentage of the ethanol extract of mericarps which used for activity studies was determined as $20.9 \%(\mathrm{w} / \mathrm{w})$.

\subsection{Morphological characteristics}

The results of macro- and micromorphological studies on mericarps of S. pilifera are illustrated in Figures 1-2. Morphometric data (i.e., size and L/W ratios of mericarp and abscission scar) are given in Table 1. Mericarps were bilaterally symmetric on the basis of the position of the abscission scar. The size of the mericarps ranged from 4.00 to $4.55 \mathrm{~mm}$ long and 3.01 to $3.48 \mathrm{~mm}$ wide. Their general shape was elliptic to widely elliptic with L/W ratios of 1.20-1.41. The apex and basal parts of the mericarps were rounded. Their shape in transverse section was rounded-trigonous. The mature mericarp color was black. The abscission scar was located at the center of the basal part and its shape was almost rounded in proximal view. The size of the abscission scar ranged from 0.63 to $0.85 \mathrm{~mm}$ long and 0.84 to $1.00 \mathrm{~mm}$ wide. The mericarp surface was glabrous and had colliculate ornamentation pattern with polygonal exocarp cells that were composed of concave linear anticlinal wall thickenings and convex and somewhat depressed outer periclinal walls.

Table 1. Summary of morphometric data recorded for S. pilifera mericarps.

\begin{tabular}{clccccc}
\hline $\begin{array}{l}\text { Mericarp } \\
\text { length } \\
(\mathbf{m m})\end{array}$ & $\begin{array}{l}\text { Mericarp } \\
\text { width } \\
(\mathbf{m m})\end{array}$ & $\begin{array}{l}\text { L/W ratio of } \\
\text { mericarp }\end{array}$ & $\begin{array}{l}\text { Abscission } \\
\text { scar length } \\
\mathbf{( m m})\end{array}$ & $\begin{array}{l}\text { Abscission } \\
\text { scar width } \\
(\mathbf{m m})\end{array}$ & $\begin{array}{l}\text { L/W ratio of } \\
\text { abscission } \\
\text { scar }\end{array}$ & $\begin{array}{l}\text { Thickness of } \\
\text { mucilage } \\
\text { layer }(\mathbf{m m})\end{array}$ \\
\hline $4.00-4.55$ & $3.01-3.48$ & $1.20-1.41$ & $0.63-0.85$ & $0.71-0.92$ & $0.84-1.00$ & $0.25-0.40$ \\
$(4.38 \pm 0.17)$ & $(3.28 \pm 0.13)$ & $(1.34 \pm 0.06)$ & $(0.73 \pm 0.07)$ & $(0.80 \pm 0.06)$ & $(0.92 \pm 0.06)$ & $(0.32 \pm 0.05)$ \\
\hline
\end{tabular}

Numbers refer to minimum-maximum (mean $\pm \mathrm{SD}$ ).

\subsection{Myxocarpy}

SM micrographs displaying myxocarpy (mucilaginous reaction) on the mericarp are presented in Figure 3. Thickness measurements for the mucilage layer are given in Table 1. Myxocarpy was present on the mericarps after the first half hour of treatment with water. Mucilaginous cells showed a moderate reaction ranging from 0.25 to $0.40 \mathrm{~mm}$. Transparent and fibreless or radiating cordons embraced by the mass of mucilage were observed.

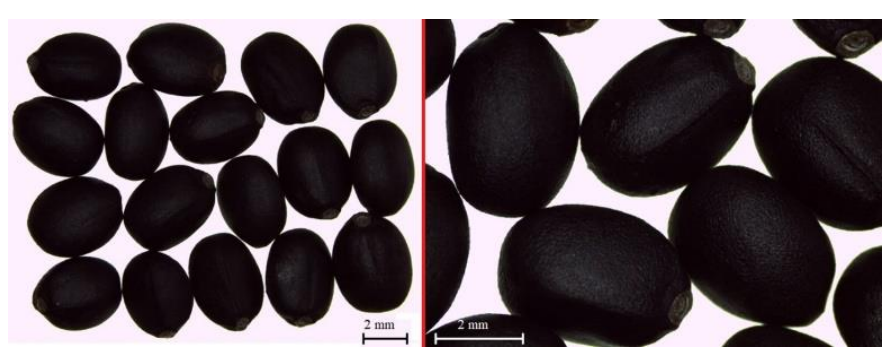

Figure 1. SM micrographs showing S. pilifera mericarps. 

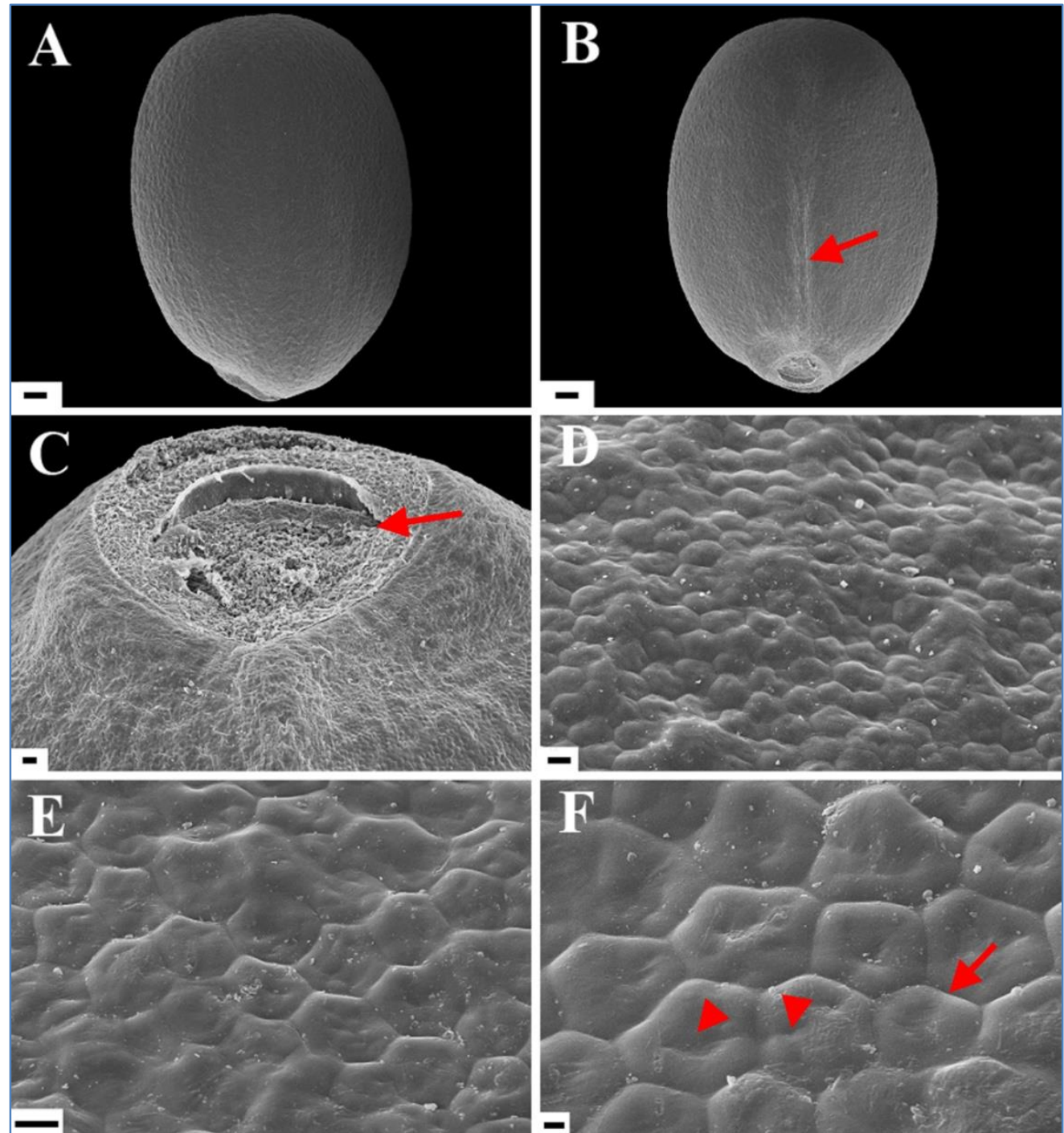

Figure 2. SEM micrographs showing S. pilifera mericarps: A. Dorsal view (x50). B. Ventral view (x50) (An arrow indicates the rib separating two of the faces); C. Detail of abscission scar area in basal region (x250) (An arrow shows a round-shaped abscission scar); D. Colliculate ornamentation pattern with polygonal cell arrangement in dorsal view (x1000); E-F. Detail of surface ornamentation in lateral view (x2000, x3000). (An arrow indicates a concave, straight anticlinal wall and arrowheads show depressions of outer periclinal cell walls with different size. Scale bars: (A-B) $200 \mu \mathrm{m},(C) 20 \mu \mathrm{m},(\mathrm{D}-\mathrm{E}) 10 \mu \mathrm{m},(\mathrm{F}) 3 \mu \mathrm{m})$
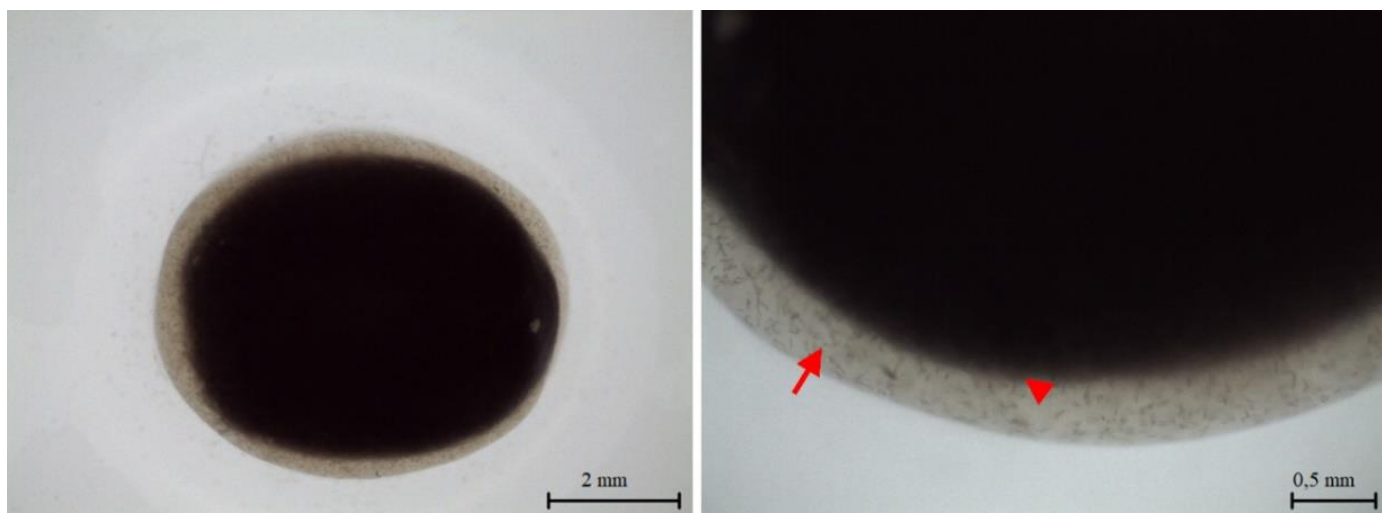

Figure 3. SM micrographs showing a moderate mucilaginous reaction $(>0.1 \mathrm{~mm}$ long) on $S$. pilifera mericarp. (An arrow indicates transparent and fibreless or radiating cordon mucilage. An arrowhead shows the outer pericarp layer). 


\subsection{Mineral analysis}

Mineral analysis results indicated that the mericarps contain macro minerals such as sodium $(\mathrm{Na})$, magnesium $(\mathrm{Mg})$, phosphorus $(\mathrm{P})$, potassium $(\mathrm{K})$, and calcium $(\mathrm{Ca})$; essential trace minerals such as manganese $(\mathrm{Mn})$, iron $(\mathrm{Fe})$, nickel $(\mathrm{Ni})$, zinc $(\mathrm{Zn})$, copper $(\mathrm{Cu})$, and selenium $(\mathrm{Se})$; and other minerals such as aluminum ( $\mathrm{Al})$, cobalt $(\mathrm{Co})$, strontium $(\mathrm{Sr})$, and molybdenum $(\mathrm{Mo}) . \mathrm{K}, \mathrm{Ca}, \mathrm{Mg}$, and $\mathrm{P}$ were found to be the major minerals with the values of $80.662 \pm 0.234 \mu \mathrm{g} / \mathrm{g}, 41.892 \pm 0.399 \mu \mathrm{g} / \mathrm{g}, 17.272 \pm 0.174 \mu \mathrm{g} / \mathrm{g}$, and $16.192 \pm$ $0.140 \mu \mathrm{g} / \mathrm{g}$, respectively. Among the essential trace minerals, amount of Fe $(1.310 \pm 0.008 \mu \mathrm{g} / \mathrm{g})$ was higher than others (Table 2).

Table 2. Mineral content of S. pilifera mericarps ( $\mu \mathrm{g} / \mathrm{g}$ dry sample).

\begin{tabular}{lcc}
\hline Minerals & Symbol & S. pilifera \\
\hline Macro minerals & $\mathrm{Na}$ & $0.488 \pm 0.005$ \\
Sodium & $\mathrm{Mg}$ & $17.272 \pm 0.174$ \\
Magnesium & $\mathrm{P}$ & $16.192 \pm 0.140$ \\
Phosphorus & $\mathrm{K}$ & $80.662 \pm 0.234$ \\
Potassium & $\mathrm{Ca}$ & $41.892 \pm 0.399$ \\
Calcium & & \\
Essential trace minerals & $\mathrm{Mn}$ & $0.311 \pm 0.003$ \\
Manganese & $\mathrm{Fe}$ & $1.310 \pm 0.008$ \\
Iron & $\mathrm{Ni}$ & $0.009 \pm 0.000$ \\
Nickel & $\mathrm{Zn}$ & $0.403 \pm 0.003$ \\
Zinc & $\mathrm{Cu}$ & $0.123 \pm 0.001$ \\
Copper & $\mathrm{Se}$ & $0.285 \pm 0.004$ \\
Selenium & & \\
Other minerals & $\mathrm{Al}$ & $0.072 \pm 0.000$ \\
Aluminum & $\mathrm{Co}$ & $0.001 \pm 0.000$ \\
Cobalt & $\mathrm{Sr}$ & $0.050 \pm 0.213$ \\
Strontium & $\mathrm{Mo}$ & $0.008 \pm 0.000$ \\
Molybdenum & & \\
\hline Data prented & & \\
\hline
\end{tabular}

Data presented as mean \pm SD.

Experiments performed triplicate.

\subsection{Antimicrobial activity}

When compared to the reference antibacterial agents Ampicillin, Isoniazid, and Ethambutol; the extract showed antibacterial activity against six bacterial strains with MIC values ranging from 250 to 62.5 $\mu \mathrm{g} / \mathrm{mL}$. The tested extract had greater antibacterial activity against gram-negative bacterial strain $A$. baumannii with a $62.5 \mu \mathrm{g} / \mathrm{mL}$ MIC value compared to reference drug Ampicillin with a $125 \mu \mathrm{g} / \mathrm{mL}$ MIC value. Additionally, the extract had antibacterial effect on gram-negative bacterial strain $A$. hydrophila compared to Ampicillin (125 $\mu \mathrm{g} / \mathrm{mL}$ and $31.25 \mu \mathrm{g} / \mathrm{mL}$ MIC values, respectively) and on $M$. tuberculosis H37Rv compared to reference drugs Isoniazid and Ethambutol $(62.5 \mu \mathrm{g} / \mathrm{mL}, 0.97 \mu \mathrm{g} / \mathrm{mL}$, and $1.95 \mu \mathrm{g} / \mathrm{mL}$ MIC values, respectively). The antifungal activity results showed that the ethanol extract exhibited lower antifungal activity with $62.5 \mu \mathrm{g} / \mathrm{mL}$ MIC value against three tested fungal strains (C. albicans, C. tropicalis, and C. glabrata) when compared to the reference drug Fluconazole with $31.25 \mu \mathrm{g} / \mathrm{mL}, 15.62 \mu \mathrm{g} / \mathrm{mL}$, and 3.90 $\mu \mathrm{g} / \mathrm{mL}$ MIC values, respectively (Table 3 ).

\subsection{Antiproliferative activity}

Cell viability of A549 human lung cancer cell lines was assessed using MTT assay to evaluate antiproliferative effect of the ethanol extract. Different concentrations including 25, 50, 100, and $200 \mu \mathrm{g} / \mathrm{mL}$ were tested. Among the all tested concentrations $(25,50,100$, and $200 \mu \mathrm{g} / \mathrm{mL}), 100 \mu \mathrm{g} / \mathrm{mL}$ concentration of the extract was found to be statistically different than control group $(\mathrm{P}<0.05)$. However, no statistically significantly differences were observed between other tested groups ( $P>0.05)$ (Figure 4$)$. 
Table 3. Minimum inhibitory concentration values of the ethanol extract and reference drugs against microbial strains $(\mu \mathrm{g} / \mathrm{mL})$.

\begin{tabular}{|c|c|c|c|c|c|}
\hline \multirow{2}{*}{ Microorganisms } & \multirow{2}{*}{$\begin{array}{c}S . \\
\text { pilifera }\end{array}$} & \multicolumn{4}{|c|}{ Reference drugs } \\
\hline & & Ampicillin & Isoniazid & Ethambutol & Fluconazole \\
\hline \multicolumn{6}{|l|}{ Bacterial strains } \\
\hline Staphylococcus aureus ATCC 25925 & 250 & 31.25 & NT & NT & NT \\
\hline Bacillus subtilis ATCC 6633 & 250 & 0.9 & NT & NT & NT \\
\hline Escherichia coli ATCC 25923 & 250 & 15.62 & NT & NT & NT \\
\hline Acinetobacter baumannii ATCC 02026 & 62.5 & 125 & NT & NT & NT \\
\hline Aeromonas hydrophila ATCC 95080 & 125 & 31.25 & NT & NT & NT \\
\hline Mycobacterium tuberculosis H37Rv & 62.5 & NT & 0.97 & 1.95 & NT \\
\hline \multicolumn{6}{|l|}{ Fungal strains } \\
\hline Candida albicans ATCC 14053 & 62.5 & NT & NT & NT & 31.25 \\
\hline Candida tropicalis ATCC 1369 & 62.5 & NT & NT & NT & 15.62 \\
\hline Candida glabrata ATCC 15126 & 62.5 & NT & NT & NT & 3.90 \\
\hline
\end{tabular}

Values determined in duplicate with deviations within one two-fold dilution.

NT: Not tested.

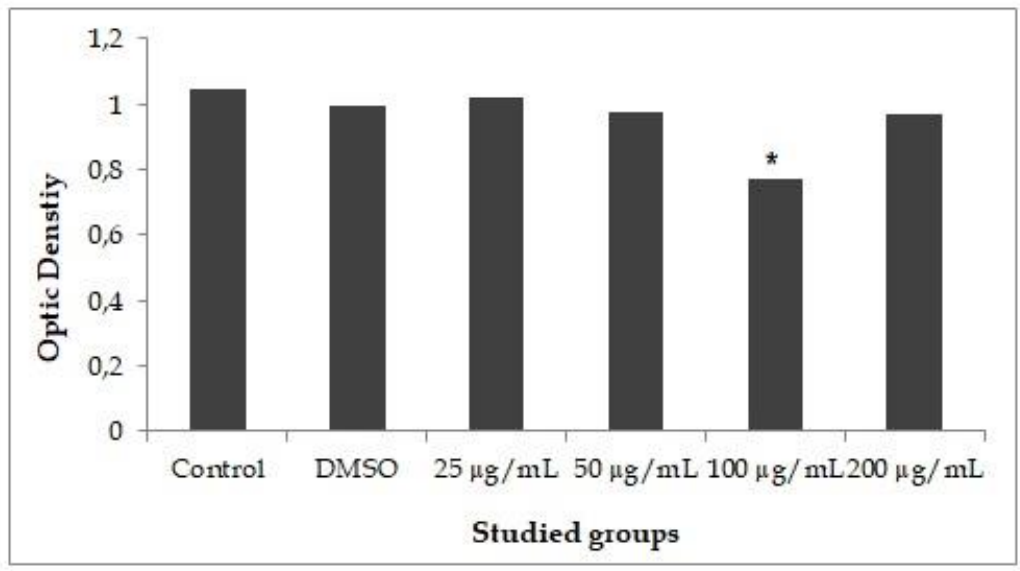

Figure 4. Antiproliferative effect of the ethanol extract obtained from mericarps of S. pilifera on A549 human lung cancer cell lines in MTT cell viability assay. $\mathrm{P}<0.05$ was considered to be significant. * Significantly different from control group. (Control, the group was not exposed any chemical, just incubated only with medium; DMSO, the group was treated medium with DMSO; $25 \mu \mathrm{g} / \mathrm{mL}$, the group was incubated with $25 \mu \mathrm{g} / \mathrm{mL}$ of the extract; $50 \mu \mathrm{g} / \mathrm{mL}$, the group was incubated with $50 \mu \mathrm{g} / \mathrm{mL}$ of the extract; $100 \mu \mathrm{g} / \mathrm{mL}$, the group was incubated with $100 \mu \mathrm{g} / \mathrm{mL}$ of the extract; $200 \mu \mathrm{g} / \mathrm{mL}$, the group was incubated with $200 \mu \mathrm{g} / \mathrm{mL}$ of the extract).

\section{DISCUSSION}

Macro- and micromorphological data offer valuable information for the classification, evolution and deduction of phylogenetic relationships of many plant groups. Mericarp and seed morphology displays low phenotypic plasticity and are less affected by environmental conditions [26]. Mericarp characters, such as mericarp size, shape and color, and ornamentation pattern of the surface, are useful in identifying species and generic levels [24]. The macro- and micromorphology of Salvia mericarps present useful discriminating characters that are adequate for identifying species [19, 21-24]. The study on mericarp morphology of 15 Turkish Salvia taxa belonging to the section Hymenosphace Benth. indicated that the morphological features of Salvia mericarps were enough to separate the taxa [24]. Our results were consistent with findings of previous studies. In the Flora of Turkey, members of the sections Plethiosphace Benth. and Hemisphace Benth. of the genus had small mericarp size with the values of 1.5-2.5 x 1.0-2.0 mm and 2.2-2.5 x 1.3-1.5 mm, respectively [27]. In our study, S. pilifera was easily distinguished from them by its larger mericarps (4.00-4.55 x 3.01-3.48 $\mathrm{mm}$ ). Mericarps of Salvia species were brown or black and rounded, trigonous or rounded-trigonous (the most common shape) in transverse section [27]. The present study showed that S. pilifera had black and rounded-trigonous mericarps in transverse section. Moon et al., [21] described four surface ornamentation patterns on mericarps of Salvia species. In most species, they observed psilate surface that is rather smooth lacking any particular ornamentation and has sometimes slightly undulate periclinal walls. Kahraman et al., [24] recognized colliculate, reticulate, verrucate and foveate ornamentation patterns on mericarp surfaces of 
taxa of section Hymenosphace. The present study indicated that S. pilifera mericarps had a colliculate surface pattern.

The mucilage production was present in nearly all of over forty Salvia species in Southwest Asia, except for only three species [19]. Most of the Salvia species had moderate or strong mucilaginous reactions [21]. Kahraman et al., [1] pointed out that morphologically related species S. napifolia Jacq. and S. russellii Benth. had similar mucilage features, supporting Hedge's [19] findings. In our study, a moderately mucilaginous reaction was observed on the pericarp surface of $S$. pilifera. Büyükkartal et al. [23] investigated mericarps of three Turkish endemics S. hedgeana Dönmez, S. huberi Hedge and S. rosifolia Sm. belonging to the section Salvia and found that $S$. huberi differed from the other species in having translucent-milky white opaque mucilage with fibres or radiating cordons. In the present study, S. pilifera had transparent mucilage without fibres or having radiating cordons, in common with S. hedgeana and S. rosfolia. The presence or absence of mucilage and its different properties might be due to differences in ecological parameters of habitats [28].

As mentioned before the mericarps of Salvia species such as Salvia hispanica L. are commercially called as seeds and have been often used in the food, medical, cosmetics, and pharmaceutical industries [11, 18]. Mineral content of $S$. hispanica seeds which are also known as chia was investigated previously and results showed that seeds contain different minerals such as $\mathrm{K}, \mathrm{Mg}, \mathrm{Ca}, \mathrm{Na}, \mathrm{Fe}, \mathrm{Zn}, \mathrm{Mn}, \mathrm{Cu}, \mathrm{Co}, \mathrm{Ni}$, and Se. $\mathrm{K}$ $(13,477.61 \pm 56.27 \mathrm{mg} / 100 \mathrm{~g}), \mathrm{Mg}(4963.81 \pm 31.80 \mathrm{mg} / 100 \mathrm{~g})$, and $\mathrm{Ca}(4221.89 \pm 232.44 \mathrm{mg} / 100 \mathrm{~g})$ were determined as major minerals [9]. Besides these minerals, the presence of Mo and $\mathrm{P}$ was shown in previous studies $[8,11]$. The present study indicated that $S$. pilifera mericarps contain fifteen different minerals including $\mathrm{Na}, \mathrm{Mg}, \mathrm{P}, \mathrm{K}, \mathrm{Ca}, \mathrm{Mn}, \mathrm{Fe}, \mathrm{Ni}, \mathrm{Zn}, \mathrm{Cu}, \mathrm{Se}, \mathrm{Al}, \mathrm{Co}, \mathrm{Sr}$, and Mo. Moreover, $\mathrm{K}(80.662 \pm 0.234 \mu \mathrm{g} / \mathrm{g}), \mathrm{Ca}$ $(41.892 \pm 0.399 \mu \mathrm{g} / \mathrm{g})$, and $\mathrm{Mg}(17.272 \pm 0.174 \mu \mathrm{g} / \mathrm{g})$ were found to be the major minerals. According to our results, the amount of Ca in S. pilifera mericarps was as high as in S. hispanica pericarps. However, the amounts of $\mathrm{Mg}$ and $\mathrm{K}$ in S. hispanica mericarps were higher than those of S. pilifera mericarps.

Antimicrobial properties of methanolic and aqueous extracts of Salvia przewalskii Maxim. seeds were investigated against bacterial and fungal strains. Among the all tested microorganisms, both tested extracts showed higher antibacterial activity against E. coli compared with referance drug streptomycin [29]. Antibacterial properties of Salvia macrosiphon Boiss. seed mucilage were studied against S. aureus and E. coli, and tested material showed antibacterial activity against both tested bacterial strains. Moreover, the result of $S$. aureus was also found to be more pronounced than the result of E. coli [30]. Antimicrobial effects of $S$. hispanica seeds were investigated against twenty microorganisms including E. coli, S. aureus, A. baumanii, and C. albicans; and aqueous and aqueous-ethanol extracts of seeds exhibited antimicrobial activity against $E$. coli [31]. Literature screening showed that, except antimicrobial study on essential oil of aerial parts of S. pilifera [25], no data was found on antimicrobial activity of S. pilifera mericarps. In the current study, the ethanol extract of S. pilifera mericarps showed antimicrobial activity against all tested microorganisms with different MIC values ranging from 250 to $62.5 \mu \mathrm{g} / \mathrm{mL}$. Due to more complex cell wall structure [16], gram-negative bacteria are more resistant than gram-positive bacteria [32]. Differentiation in outer membrane arrangement of both gram-negative and gram-positive bacteria affects penetration of macromolecules variously during treatment [16]. Also, gram-negative bacteria are more resistant against natural components than grampositive bacteria. The hydrophilic cell wall structure, which contains lipopolysaccharides, inhibits accumulation of hydrophobic oils and extracts, and penetration of these substances through the target cell membrane in gram-negative bacteria [32]. In our study, the extract exhibited antibacterial activity against both gram-negative and gram-positive bacterial strains; therefore, our results supported literature data mentioned above. Additionally, the extract showed greater antibacterial activity against gram-negative nosocomial pathogen A. baumannii, which is one of the important healthcare problem worldwide because of its ability to gain resistance to all classes of antimicrobial agents used against it [33]. Recently, A. baumannii has received attention in intensive care units and is known to be responsible for various infections such as ventilator-associated pneumonia, meningitis, bacteremia, and infections of surgical wounds, urinary tract, and bloodstream [34].

Antiproliferative effect of different parts of some Salvia species have been reported previously [14, 15], while there was a few studies reported on Salvia seeds. Effects of four compounds obtained from mucilage of S. hispanica seeds were investigated against eight cancer lines [colon (HCT-15 and HCT-116), cervix (HeLa), breast (MCF7 and MDA-MB-231) carcinoma cell lines, MCF7/Vin+, MCF7/Vin, MCF7/Vin- cells, and Vero cells], and compounds were significantly inhibited the proliferation of HeLa, MCF7, and HepG2 cells with low toxicity in a normal cell model [35]. In the literature, cytotoxic effects on DU145 prostate cancer cell lines 
of dichloromethane and methanol extracts of S. pilifera were studied [15]; however, we didn't reach any available literature on antiproliferative effects of S. pilifera mericarps. According to the 5 year survival rate of patients with lung cancer which is one of the serious types of malignant tumor with a high mortality, is $73 \%$ [36]. Our results indicated that at a concentration of $100 \mu \mathrm{g} / \mathrm{mL}$ ethanol extract of S. pilifera mericarps exhibited antiproliferative effect on A549 human lung cancer cell lines.

\section{CONCLUSION}

The present study is the first detailed findings on micromorphology, myxocarpy, mineral content, and in vitro antimicrobial and antiproliferative activities of the mericarps of S. pilifera. Mericarp morphology can be used as a valuable tool for the species identification. Additionally, results of mineral content and in vitro activity studies on mericarps of S. pilifera revealed that mericarps of the plant could be promising agents in pharmaceutical industry due to their antimicrobial activity on A. baumannii and antiproliferative activity on A549 human lung cancer cell lines, and food industry due to their mineral content with rich source of $\mathrm{K}, \mathrm{Ca}$, $\mathrm{Mg}$, and P. However, further studies are needed to confirm medicinal properties and nutritional potential of the mericarps of S. pilifera. Due to lack of knowledge in micromorphology, myxocarpy, mineral content, and in vitro antimicrobial and antiproliferative activities of those of many Salvias species, further studies are required in the fields mentioned.

\section{MATERIALS AND METHODS}

\subsection{Chemicals}

Ethanol (EtOH), Isoniazid, Fluconazole, Ethambutol, RPMI 1640 Medium, 3-(N-morpholino)propanesulfonic acid, Resazurin sodium salt powder, dimethyl sulfoxide (DMSO), Trypsin-EDTA solution, (3- [4,5- dimethylthiazol- 2- yl]- 2,5- diphenyl- tetrazolium bromide) (MTT), Dulbecco's modified eagle's medium (DMEM), and Fetal calf serum (FCS) were purchased from Sigma-Aldrich (St. Louis, MO, USA). Middlebrook 7H9 broth, casitone, glycerol, and oleic acid-albumin-dextrose-catalase were purchased from Becton Dickinson (Sparks, MD, USA). The all solutions were prepared with distilled water and freshly prepared solutions were used.

\subsection{Microbial strains}

Two gram-positive bacterial strains [Staphylococcus aureus (ATCC 25925) and Bacillus subtilis (ATCC 6633)], three gram-negative bacterial strains [Escherichia coli (ATCC 25923), Acinetobacter baumannii (ATCC 02026), and Aeromonas hydrophila (ATCC 95080)], and Mycobacterium tuberculosis H37Rv; and three fungal strains [Candida albicans (ATCC 14053), Candida tropicalis (ATCC 1369), and Candida glabrata (ATCC 15126)] were purchased from the Refik Saydam Hifzıssihha Institute, Ankara, Turkey.

\subsection{Cell culture}

A549 human lung cancer cell lines were purchased from ATCC (American Type Culture Collection, VA, USA). For cell culture, DMEM which contains 10\% FCS was used. Cells were put into suitable culture conditions including air, $95 \%$; carbon dioxide $5 \%$; temperature, $37^{\circ} \mathrm{C}$.

\subsection{Plant material and extraction procedure}

Specimens of S. pilifera were collected from its natural habitat during field work in Southeast Anatolia. Identification and confirmation of the collected specimens were performed by Dr. Ahmet Kahraman. Samples were kept in the Plant Systematics and Phylogenetics Research Laboratory at Uşak University. Sample details are as follows: Adıyaman, Gerger, Kaşyazı village, in Quercus forest, c. 1200 m, 02.06.2015, A. Kahraman 2081B.

The powdered mericarps were extracted twice with ethanol (96\%), sonicated for $1 \mathrm{~h}$ and left overnight at room temperature with shaking then filtered using Whatman Grade No.1 filter paper. After filtration, solvent was evaporated using a vacuum evaporator (Heidolph-Rotary TLR 1000, Heidolph Instruments $\mathrm{GmbH} \& \mathrm{Co}$., Schwabach, Germany) at $35-40{ }^{\circ} \mathrm{C}$ and extract was stored in the dark at $4{ }^{\circ} \mathrm{C}$ until further use.

\subsection{SM studies}

The mericarps were first examined with a stereo microscope (Leica S6D, Leica Microsystems, Wetzlar, Germany), equipped with a digital camera (Leica EC3, Leica Microsystems, Wetzlar, Germany) to ensure 
that they were of normal size and maturity. With the help of LAS EZ software multiple photographs were taken and mericarp measurements were made. The thirty ripe mericarps were measured to determine length $(\mathrm{L})$, width $(\mathrm{W})$ and $\mathrm{L} / \mathrm{W}$ ratio of the mericarps and abscission scars. Each quantitative character was analyzed for its range, mean and standard deviation values. Qualitative characteristics (i.e., mericarp shape and color, and abscission scar shape) were recorded. For the screening of the presence of a mucilaginous reaction, ten mericarps were treated with distilled water, following Ryding [20]. Then, they were examined under different magnifications $(8 x-40 x)$ using the stereo microscope coupled with the camera. The terminology of mucilage characteristics (i.e, color, consistency and general appearance) followed Hedge [19].

\subsection{SEM studies}

Five selected representative mericarps were mounted directly on aluminum stubs with double-sided sticky tape and coated in a sputter coater with a thin layer of gold. Detailed observations of lateral and dorsal sides of the mericarps were carried out under various magnifications (50x-3000x) using scanning electron microscopy (LEO-1430 VP SEM, Carl Zeiss SMT, Oberkochen, Germany) at an accelerating voltage of $20 \mathrm{kV}$. The ornamentation pattern of the mericarp surface is described based on the primary sculpturing, shape of anticlinal and periclinal cell walls, and relief of cell boundaries, following Budantsev and Lobova [37].

\subsection{Mineral analysis}

Mineral analysis was performed according to the method mentioned in Basgel and Erdemoglu [12]. CEM MARS 240/50 (CEM Co., NC, USA) oven with a timer and different temperature setting system was used for microwave-assisted digestion. Thermo Scientific ${ }^{\mathrm{TM}}$ iCAP Q ICP-MS (Thermo Scientific, Waltham, USA) was used for analysis. Analyses were performed triplicates. Experimental conditions are as follows: auto sampler, Cetac ASX-520; torch, Quartz; Rf power, $1548.6 \mathrm{~W}$; auxiliary flow, $0.79 \mathrm{~L} / \mathrm{min}$; nebulizer flow, $0.94 \mathrm{~L} / \mathrm{min}$; detector voltage, $1189 \mathrm{~V}$; spray chamber temperature, $2.55^{\circ} \mathrm{C}$; read time, $0.01 \mathrm{sec}$; delay time, 30 $\mathrm{sec}$; and wash time, $30 \mathrm{sec}$. The results were expressed in $\mu \mathrm{g} / \mathrm{g}$ of dry sample and given as the mean \pm standard deviation (SD).

\subsection{Antimicrobial studies}

\subsubsection{Antibacterial activity}

Antibacterial activity of the extract was tested against two gram-positive and three gram-negative bacterial strains using a broth microdilution method. Ampicillin was used as a reference drug. To obtain an initial concentration of $2000 \mu \mathrm{g} / \mathrm{mL}$, extract was dissolved in DMSO to prepare stock solutions which were diluted in Mueller-Hinton broth. Dilution series of the extract and Ampicillin were prepared $(1000,500,250$, $125,62.5,31.25,15.62,7.8,3.9$ and $1.9 \mu \mathrm{g} / \mathrm{mL}$ ). Working suspensions of each standard strain were made in sterile tubes and turbidity adjusted to match McFarland standard No: 0.5. Each suspension was diluted (1:20) using distilled water, then $10 \mu \mathrm{L}$ of each diluted suspension was added to each plate, therefore, bacterial concentration of each plate adjusted to $5 \times 10^{5} \mathrm{CFU} / \mathrm{mL}$. Effect of DMSO on microbial growth was tested, no effect determined. The minimal inhibitory concentration (MIC) values were detected in duplicate tests [13].

\subsubsection{Antimycobacterial activity}

Antimycobacterial activity of the extract was tested against $M$. tuberculosis $\mathrm{H} 37 \mathrm{Rv}$ standard strain using the resazurin microtiter assay plate method. Ethambutol and Isoniazid were used as reference drugs. Experiments were performed in duplicate. 7H9-S medium was used with Middlebrook 7H9 broth containing $0.1 \%$ casitone, $0.5 \%$ glycerol, and $10 \%$ oleic acid-albumin-dextrose-catalase for preparing culture medium and resazurin sodium salt powder was used for preparing resazurin reagent. A working solution was prepared in distilled water $(0.01 \%(\mathrm{w} / \mathrm{v})$ concentration). Stock solutions of extract and reference drugs were made in DMSO at a concentration of $1000 \mu \mathrm{g} / \mathrm{mL}$. In a 96-well microtiter plate, a two-fold dilution series of solutions was prepared with 7H9-S $(100 \mu \mathrm{L})$. Concentration ranges between $250-0.12 \mu \mathrm{g} / \mathrm{mL}$ were tested. A growth control containing no antibiotic and a sterility control without inoculum were added to each plate. The H37Rv inoculum was prepared via resuspending a loopful of Lowenstein-Jensen culture medium in a tube containing 7H9-S medium $(5 \mathrm{~mL})$ with several glass beads. The tube was vortexed for 2 min and then let sit to allow sediment formation for $30 \mathrm{~min}$. The supernatant was kept in sterile tubes and the turbidity adjusted to match McFarland standard No: 1 and this suspension was diluted in 7H9-S (1:20). Studied plates 
were inoculated with the suspension $(100 \mu \mathrm{L})$, put into plastic bags and incubated at $37^{\circ} \mathrm{C}$ for 7 days in normal atmosphere. After incubation, resazurin working solution $(30 \mu \mathrm{L})$ was added to each well. The plates were incubated at $37^{\circ} \mathrm{C}$ for $24 \mathrm{~h}$. Finally, the results were noted visually. Color changes (blue to pink) showed reduction of resazurin which meant bacterial growth. For having positive results, the color changes indicating growth had to be comparable to that seen in the positive growth control. The lowest concentration which prevented full color changes of resazurin was determined as the MIC value [13].

\subsubsection{Antifungal activity}

The antifungal activity of the extract was tested using a broth microdilution method against three fungal strains with respect to the standard document (M27-A2) of NCCLS [38]. Fluconazole was used as a reference antifungal agent. As mentioned in the standard document, experiments were performed in RPMI 1640 medium buffered to $\mathrm{pH} 7.0$ with $0.165 \mathrm{M} 3$-(N-morpholino) propanesulfonic acid. Each standard strain's working suspension was prepared with RPMI 1640 medium at a 1:100 dilution then 1:20 dilution of the stock suspension was prepared. Stock solutions $(1000 \mu \mathrm{g} / \mathrm{mL})$ of the extract and reference drug were prepared using DMSO. Then a two-fold dilution series of reference drug and solutions were put into a 96well microtiter plate using RPMI 1640 medium $(100 \mu \mathrm{L})$. Concentration ranges between $250-0.12 \mu \mathrm{g} / \mathrm{mL}$ were tested. A growth control containing no antibiotic and a sterility control without inoculum were added to each plate. Then the working inoculum suspension $(100 \mu \mathrm{L})$ was pipetted into each plate and all plates were incubated for $48 \mathrm{~h}$ in ambient air at $35^{\circ} \mathrm{C}$. Experiments were performed in duplicate and visually detected results were noted. The lowest concentration that inhibited growth of the studied microorganism was determined as a MIC value $[13,38]$.

\subsection{Antiproliferative study}

\subsubsection{Cell viability test}

The cell viability test was performed using MTT colorimetric assay. After getting $70-80 \%$ confluency, cells were detached via Trypsin-EDTA solution $(3.0 \mathrm{~mL})$ and seeded to 96 -well plates $\left(10^{4}\right.$ cell per well) then incubated for $24 \mathrm{~h}$. After incubation, different concentrations $(25,50,100$, and $200 \mu \mathrm{g} / \mathrm{mL})$ of the extract prepared in DMSO were applied and incubated for $24 \mathrm{~h}$. After incubation, the supernatants were replaced with MTT $(1 \mathrm{mg} / \mathrm{mL})$ which dissolved in growth medium and incubated at $37^{\circ} \mathrm{C}$ until purple precipitate is visually detected. After incubation, supernatants were removed. MTT absorbed by cells were dissolved in DMSO. Results were evaluated using a spectrophotometer (Epoch, BioTek Instruments, VT, USA) at $550 \mathrm{~nm}$. Experiments were performed in four replicates. The growth medium not supplemented with FCS was used as a control group. Additionally, effect of DMSO was tested and no statistically significant effect was determined [15].

\subsection{Statistical analysis}

The statistical analyses were performed using SPSS 25.0 (IBM, NY, USA). The data are represented as the mean \pm SD. Antiproliferative study results were evaluated using Kruskal Wallis $\mathrm{H}$ and one-way analysis of variance (ANOVA) with Tukey's post hoc test. P values $<0.05$ were considered as statistically significant.

Acknowledgements: We offer grateful thanks to Lecturer Serhat Tikız at The Technology Application and Research Centre (TUAM), Afyon Kocatepe University (Afyonkarahisar, Turkey) for taking excellent SEM micrographs; Dr. Erkan Halay at Scientific Analysis and Technological Research and Application Center (UBATAM), Usak University (Usak, Turkey) for ICP analysis.

Author contributions: Concept - S.G., A.K.; Design - S.G., A.K.; Supervision - S.G., A.K.; Materials - S.G., A.K., M.Ü., Y.Ö., İ.B., Ö.S.; Data Collection and/or Processing - S.G., A.K., M.Ü., Y.Ö., İ.B.; Analysis and/or Interpretation - S.G., A.K., M.Ü., Y.Ö., İ.B., Ö.S.; Literature Search - S.G., A.K., M.Ü.; Writing - S.G., A.K.; Critical Reviews - S.G., A.K., M.Ü., Y.Ö., İ.B., Ö.S.

Conflict of interest statement: The authors declared no conflict of interest. 


\section{REFERENCES}

[1] Kahraman A, Buyukkartal HN, Dogan M. Pericarp ultrastructure of Salvia section Hemisphace (Mentheae; Nepetoideae; Lamiaceae). Commagene J Biol. 2018; 2(1): 1-7. [CrossRef]

[2] Kamatou GPP, Makunga NP, Ramogola WPN, Viljoen AM. South African Salvia species: a review of biological activities and phytochemistry. J Ethnopharmacol. 2008; 119: 664-672. [CrossRef]

[3] Topcu G, Turkmen Z, Schilling JK, Kingston DGI, Pezzuto JM, Ulubelen A. Cytotoxic activity of some Anatolian Salvia extracts and isolated abietane diterpenoids. Pharm Biol. 2008; 46(3): 180-184. [CrossRef]

[4] Baytop T, Therapy with Medicinal Plants in Turkey (Past and Present), Nobel Medical Presshouse, Istanbul, Turkey 1999.

[5] Perry N, Court G, Bidet N, Court J, Perry E. European herbs with cholinergic activities: potential in dementia therapy. Int J Geriatr Psychiatry. 1996; 11: 1063-1069. [CrossRef]

[6] Kirmizibekmez H, Bardakci Altan H, Liktor-Busa E, Zana A, Yesilada E, Hohmann J. Chemical constituents of Salvia dichroantha. Biochem Syst Ecol. 2012; 42: 18-20. [CrossRef]

[7] Temel HE, Demirci B, Demirci F, Celep F, Kahraman A, Doğan M, Başer KHC. Chemical characterization and anticholinesterase effects of essential oils derived from Salvia species. J Essent Oil Res. 2016; 28(4): $322-331$. [CrossRef]

[8] Ullah R, Nadeem M, Khalique A, Imran M, Mehmood S, Javid A, Hussain J. Nutritional and therapeutic perspectives of Chia (Salvia hispanica L.): a review. J Food Sci Technol. 2016; 53(4): 1750-1758. [CrossRef]

[9] Ding Y, Lin H, Lin Y, Yang D, Yu Y, Chen R, Wang S, Chen Y. Nutritional composition in the chia seed and its processing properties on restructured ham-like products. J Food Drug Anal. 2018; 26: 124-134. [CrossRef]

[10] Ozkan G, Gokturk RS, Kiralan M, Ramadan MF. Fatty acids and tocopherols of Turkish Salvia fruticose, Salvia tomentosa, Stachys aleurites and Stachys cretica subsp. anatolica seed oils. Riv Ital Sostanze Gr. 2018; 95: 17-21.

[11] Muñoz LA, Cobos A, Diaz O, Aguilera JM. Chia seed (Salvia hispanica): an ancient grain and a new functional food. Food Rev Int. 2013; 29: 394-408. [CrossRef]

[12] Basgel S, Erdemoglu SB. Determination of mineral and trace elements in some medicinal herbs and their infusions consumed in Turkey. Sci Total Environ. 2006; 359: 82-89. [CrossRef]

[13] Guzel S, Ozay Y, Kumas M, Uzun C, Gokalp Ozkorkmaz E, Yildirim Z, Ulger M, Guler G, Celik A, Camlica Y, Kahraman A. Wound healing properties, antimicrobial and antioxidant activities of Salvia kronenburgii Rech. f. and Salvia euphratica Montbret, Aucher \& Rech. f. var. euphratica on excision and incision wound models in diabetic rats. Biomed Pharmacother. 2019; 111: 1260-1276. [CrossRef]

[14] Jian Y, Zhang L, Rupasinghe HP. Antiproliferative effects of extracts from Salvia officinalis L. and Saliva miltiorrhiza Bunge on hepatocellular carcinoma cells. Biomed Pharmacother. 2017; 85: 57-67. [CrossRef]

[15] Yumrutas O, Pehlivan M, Guven C, Bozgeyik I, Bozgeyik E, Yumrutas P, Temiz E, Uckardes F. Investigation of cytotoxic effect of Salvia pilifera extracts and synthetic chlorogenic and caffeic acids on DU145 prostate cancer cells line. KSU J Agric Nat. 2018; 21(2): 141-147. [CrossRef]

[16] Alimpić A, Knežević A, Milutinović M, Stević T, Šavikin K, Stajić M, Marković S, Marin P, Matevski V, DuletićLaušević S. Biological activities and chemical composition of Salvia amplexicaulis Lam. extracts. Ind Crops Prod. 2017; 105: 1-9. [CrossRef]

[17] Kahraman A, Bagherpour S, Karabacak E, Dogan M, Dogan HM, Uysal I, Celep F. Reassessment of conservation status of the genus Salvia (Lamiaceae) in Turkey II. Turk J Bot. 2012; 36: 103-124. [CrossRef]

[18] Zona S. Fruit and seed dispersal of Salvia L. (Lamiaceae): A review of the evidence. Bot Rev. 2017; 83: 195-212. [CrossRef]

[19] Hedge IC. Observations on the mucilage of Salvia fruits. Notes R Bot Garden Edinb. 1970; 30: 79-95.

[20] Ryding O. The distribution and evolution of myxocarpy in Lamiaceae. In: Harley RM, Reynolds T. (Eds). Advances in Labiatae Science. Royal Botanic Gardens, Kew, 1992, pp. 85-96.

[21] Moon HK, Hong SP, Smets E, Huysmans S. Micromorphology and character evolution of nutlets in tribe Mentheae (Nepetoideae, Lamiaceae). Syst Bot. 2009; 34: 760-776. [CrossRef]

[22] Kahraman A, Dogan M, Celep F, Akaydin G, Koyuncu M. Morphology, anatomy, palynology and nutlet micromorphology of the rediscovered Turkish endemic Salvia ballsiana (Lamiaceae) and their taxonomic implications. Nord J Bot. 2010; 28: 91-99. [CrossRef] 
[23] Buyukkartal HN, Kahraman A, Çölgeçen H, Doğan M, Karabacak E. Mericarp micromorphology and anatomy of Salvia hedgeana Dönmez, S. huberi Hedge and S. rosifolia Sm. (section Salvia Hedge, Lamiaceae). Acta Bot Croat. 2011; 70(1): 65-80. [CrossRef]

[24] Kahraman A, Celep F, Doğan M, Guerin G, Bagherpour S. Mericarp morphology and its systematic implications for the genus Salvia L. section Hymenosphace Benth. (Lamiaceae) in Turkey. Plant Syst Evol. 2011; 292: 33-39. [CrossRef]

[25] Kelen M, Tepe B. Chemical composition, antioxidant and antimicrobial properties of the essential oils of three Salvia species from Turkish flora. Bioresour Technol. 2008; 99: 4096-4104. [CrossRef]

[26] Zorić L, Merkulov L, Lukvić J, Boža P. Comparative seed morphology of Trifolium L. species (Fabaceae). Period Biol. 2010; 112(3): 263-272.

[27] Hedge IC. Flora of Turkey and the East Aegean Islands. In: Davis PH. (Eds). Salvia L., Edinburgh University Press, Edinburgh, 1982, Vol. 7, pp. 400-461.

[28] Karaismailoglu MC. Seed mucilage contents in some taxa of Aubrieta Adans. genus (Brassicaceae) and their systematic importance. Turk J Life Sci. 2017; 2: 145-148.

[29] Alsirrag M, Ali R. Determination of antimicrobial and antioxidants activity of Salvia przewalskii seed oil against pathogenic bacteria and fungi. IOP Conf Series, Journal of Physics, Conf Series. 2018; 1032: 012070. [CrossRef]

[30] Davachi SM, Shekarabi AS. Preparation and characterization of antibacterial, eco-friendly edible nanocomposite films containing Salvia macrosiphon and nanoclay. Int J Biol Macromol. 2018; 113: 66-72. [CrossRef]

[31] Kobus-Cisowska J, Szymanowska D, Maciejewska P, Kmiecik D, Gramza-Michalowska A, Kulczyński B, CieleckaPiontek J. In vitro screening for acetylcholinesterase and butyrylcholinoesterase inhibition and antimicrobial activity of chia seeds (Salvia hispanica). Electron J Biotechnol. 2019; 37: 1-10. [CrossRef]

[32] Bajpai VK. Antimicrobial bioactive compounds from marine algae: a mini review. Indian J Geomarine Sci. 2016; 45: 1076-1085.

[33] Lean SS, Yeo CC. Small, enigmatic plasmids of the nosocomial pathogen, Acinetobacter baumannii: good, bad, who knows? Front Microbiol. 2017; 8: 1547-1555. [CrossRef]

[34] Shamsizadeh Z, Nikaeen M, Esfahani BN, Mirhoseini SH, Hatamzadeh M, Hassanzadeh A, Detection of antibiotic resistant Acinetobacter baumannii in various hospital environments: potential sources for transmission of Acinetobacter infections. Environ Health Prev Med. 2017; 22: 1-7. [CrossRef]

[35] Rosas-Ramírez DG, Fragoso-Serrano MF, Escandón-Rivera S, Vargas-Ramírez AL, Reyes-Grajeda JP, SorianoGracía M. Resistance-modifying activity in vinblastine-resistant human breast cancer cells by oligosaccharides obtained from mucilage of chia seeds (Salvia hispanica). Phytother Res. 2017; 31: 906-914. [CrossRef]

[36] Jiang S, Gao Y, Hou W, Liu R, Qi X, Xu X, Li J, Bao Y, Zheng H, Hua B. Sinomenine inhibits A549 human lung cancer cell invasion by mediating the STAT3 signaling pathway. Oncol Lett. 2016; 12: 1380-1386. [CrossRef]

[37] Budantsev AL, Lobova TA. Fruit morphology, anatomy and taxonomy of tribe Nepeteae (Labiatae). Edinb J Bot. 1997; 54(2): 183-216. [CrossRef]

[38] NCCLS. Reference Method for Broth Dilution Antifungal Susceptibility Testing of Yeasts; Approved StandardSecond Edition. NCCLS document M27-A2 (ISBN 1-56238-469-4). NCCLS, 940 West Valley Road, Suite 1400, Wayne, Pennsylvania 19087-1898 USA 2002. 